\title{
ANALISIS PENDAPATAN PETERNAK AYAM BROILER PADA POLA KEMITRAAN YANG BERBEDA DI KECAMATAN PAYAKUMBUH TIMUR (Studi Kasus PT. Karya Semangat Mandiri (KSM) dan Poultry Shop Torang))
}

(Analysis of Broiler Chicken Income at Different Partnership Patterns in East Payakumbuh District (A Case Study of PT. Karya Semangat Mandiri (KSM) and Torang Poultry Shop))

\author{
Ali Makmur ${ }^{1}$, Maryega Antoni ${ }^{2}$, Arfa' $^{\prime 2}$ dan Rahmi Wati ${ }^{2}$ \\ ${ }^{1}$ Fakultas Pertanian Universitas Syiah Kuala \\ ${ }^{2}$ Fakultas Peternakan Universitas Andalas \\ Email: alimakmur379@yahoo.co.id
}

\begin{abstract}
This study aimed to determine the partnership pattern and the income of broiler breeders partnering with PT. Karya Semangat Mandiri (KSM) and Torang Poultry Shop in East Payakumbuh District. The census method was used in this study through a survey method and direct observation in the field using a questionnaire involving 12 broiler breeders who partnered with PT. KSM and ten broiler breeders who partnered with Torang Poultry Shop. Descriptive qualitative and quantitative analyses were used to analyze the data by observing the patterns and calculating the costs, income, and revenues. The results of the study indicated that the breeders partnered with PT. KSM adopted a plasma core partnership pattern with a written agreement, and the farmers were required to place a security deposit to the company. The farmer who partnered with Torang Poultry Shop used a profitsharing pattern in which the benefits were equally shared. The agreement was not in written form, and the farmers did not provide a security deposit. The income of farmers partnered with PT. KSM was higher compared to income of the farmers partnered with the Torang Poultry Shop.
\end{abstract}

Keywords: Broiler chicken, Partnership, Income

ABSTRAK

Penelitian ini bertujuan untuk mengetahui pola kemitraan serta pendapatan peternak ayam broiler yang bermitra dengan PT. Karya Semangat Mandiri (KSM) dan Poultry Shop Torang di Kecamatan Payakumbuh Timur. Penelitian ini menggunakan metode survey dan observasi langsung kelapangan menggunakan quisioner, dengan 12 orang peternak yang bermitra dengan PT. KSM dan 10 orang peternak yang bermitra dengan Poultry Shop Torang dilakukan secara sensus. Analisis data mengguanakan deskriptif kualitatif dan kuantitatif melihat pola dan menghitung biaya, penerimaan, serta pendapatan. Hasil yang didapat pada penelitian ini adalah peternak yang bermitra dengan PT. KSM menggunakan pola kemitraan inti plasma dengan perjanjian tertulis dan peternak memberikan uang jaminan kepada perusahaan, peternak yang bermitra dengan Poultry Shop Torang menggunakan pola bagi hasil yang keuntungannya di bagi dua. Bentuk perjanjian tidak dilakukan secara tertulis dan peternak tidak memberikan uang jaminan. Pendapatan peternak yang bermitra dengan PT. KSM lebih tinggi dibandingkan dengan pendapatan peternak yang bermitra dengan Poultry Shop Torang.

Kata kunci : Ayam broiler, Kemitraan, Pendapatan

\section{PENDAHULUAN}

Usaha peternakan mempunyai prospek yang cukup menjanjikan untuk dikembangkan, baik dalam skala peternakan kecil (peternakan rakyat) maupun dalam skala besar (perusahaan). Berbagai macam usaha peternakan yang banyak dikembangkan salah satunya yaitu peternakan ayam broiler. Pengembangan usaha peternakan ayam broiler di Indonesia dapat dilihat berdasarkan populasi ayam broiler dari data Badan Pusat Statistik Indonesia dengan nilai pada tahun 2015 adalah 1.528.329.183 ekor dan terjadi peningkatan pada tahun 2016 menjadi 1.632.567.839 ekor (BPS, 2017). Kota Payakumbuh termasuk kedalam salah 
satu sentra peternakan unggas di Provinsi Sumatera Barat, populasi ayam broiler di Kota Payakumbuh mendapatkan urutan ke tujuh terbesar di Sumatera Barat dengan jumlah populasi 1.144.000 ekor (BPS Sumatera Barat, 2017). Kota Payakumbuh daerah yang populasi ternak ayam broiler terbanyak yaitu terletak di Kecamatan Payakumbuh Timur. Populasi ayam broiler di Kecamatan Payakumbuh Timur yaitu sebesar 778.000 ekor (BPS Kota Payakumbuh, 2017).

Sistem pemeliharaan ayam broiler di Kecamatan Payakumbuh Timur 95\% peternak menggunakan pola kemitraan dengan perusahaan dan Poultry Shop serta mitra perorangan. Kemitraan usaha peternakan adalah kerja sama antar usaha peternakan atas dasar prinsip saling memerlukan, memperkuat, menguntungkan, menghargai, bertanggung jawab, dan ketergantungan (Soekatawi, 2006). Sistem pemeliharaan ayam broiler dengan menggunakan pola kemitraan berfungsi untuk mengatasi berbagai macam permasalahan, salah satunya keterbatasan modal. Kecamatan Payakumbuh Timur terdapat tiga perusahaan mitra yang bekerja sama dengan peternak ayam broiler diantaranya Perusahaan PT. KSM (Karya Semangat Mandiri) dan Poultry Shop yang melakukan kemitraan dengan peternak.

PT. KSM adalah salah satu perusahaan kemitraan ayam broiler yang sedang berkembang di Kota Payakumbuh, perusahaan ini berpusat di Kota Padang. Perusahaan ini berdiri dari tahun 2007 sampai dengan sekarang. Dari data yang didapatkan dari kantor Kecamatan Payakumbuh Timur 40\% peternak diwilayah Payakumbuh Timur bermitra dengan Perusahaan PT. KSM dan 33,33\% bermitra dengan Poultry Shop Torang jumlah ini menunjukkan bahwa persentase peternak yang bermitra dengan PT. KSM dan Poultry Shop lebih banyak dibandingkan dengan perusahaan kemitraan lain. Hal ini karena PT. KSM tidak mengalami keterlambatan dalam mengisi kandang kembali setelah masa kosong kandang, namun ada beberapa kendala dalam bermitra yaitu PT. KSM membatasi perjanjian kerjasama dengan peternak, dengan persyaratan peternak harus memiliki kapasitas kandang $\geq 3.500$ ekor ayam, peternak harus memberikanuangjaminan kepada pihak perusahaan, produksi ayam sering mengalami masalah seperti ayam sering stres dan sakit akibat kurang bagusnya bibit yang diberikan perusahaan kepada peternak sehingga produksi ayam broiler yang dihasilkan rendah ini sangat mempengaruhi pendapatan yang diterima oleh peternak, serta sistem kerja yang dilaksanakan oleh peternak dan perusahaan menggunakan kerja sama kemitraan inti plasma dengan mekanisme harga doc, pakan dan harga ayam pada saat panen telah ditentukan oleh perusahaan (BPS Kota Payakumbuh, 2017).

Selain bekerjasama dengan perusahaan kemitraan, peternak juga bekerjasama dengan Poultry Shop yang juga memfasilitasi peternak untuk melakukan kemitraan. Poultry Shop yang melakukan kemitraan dengan peternak di Kecamatan Payakumbuh Timur yaitu Poultry Shop Torang. Poultry Shop Torang merupakan perusahaan yang lebih dominan bergerak dibidang penjualan pakan ternak unggas yang berlokasi di Tolang, Kota Nan Ampek, Kota Payakumbuh. Poultry Shop Torang juga menjual bibit, obat-obatan ternak dan berbagai peralatan peternakan ayam broiler. Peternak yang memiliki kandang dengan kapasitas dibawah 3.500 ekor banyak bermitra dengan Poultry Shop Torang, hal ini dikarenakan Poultry Shop Torang tidak meminta uang jaminan kepada peternak. Kendala yang sering dialami oleh peternak yang bemitra dengan Poultry Shop Torang harga pakan dan DOC lebih mahal dibandingkan dengan harga pakan dan DOC yang terdapat pada PT. Karya Semangat Mandiri, total pendapatan dari hasil penjualan juga harus dibagi dua antara peternak dan Poultry Shop Torang sedangkan biaya produksi ditanggung oleh peternak sendiri sehingga sangat berpengaruh terhadap pendapatan peternak. Hoddi et al. (2011) menyatakan bahwa keuntungan yang diperoleh peternak ayam broiler (pedaging) merupakan hasil dari penjualan ternak dikurangi dengan biaya-biaya yang dikeluarkan selama masa produksi.

Berdasarkan permasalahan tersebut, maka perlu diketahui seberapa besar perbandingan pendapatan peternak yang bermitra dengan perusahaan PT. KSM dengan Poultry Shop Torang sehingga bisa dijadikan acuan untuk pengambilan keputusan dalam memilih mitra. Tujuan penelitian untuk menganalisis pola kemitraan yang dilakukan peternak, pendapatan peternak yang bermitra dengan PT. Karya Semangat Mandiri (KSM) dan Poultry Shop Torang.

\section{MATERI DAN METODE}

\section{Tempat dan waktu}

Penelitian ini dilaksanakan pada peternak ayam broiler yang berlokasi di Kecamatan 
Payakumbuh Timur, Kota Payakumbuh. Pemilihan lokasi dilakukan merupakan daerah pengembangan peternakan ayam broiler yang terbesar di Kota Payakumbuh. Pengambilan data dilakukan selama satu bulan yaitu pada bulan April sampai dengan bulan Mei 2018.

\section{Metode penelitian}

Penelitian ini dilakukan menggunakan metode survei dan observasi langsung ke lapangan menggunakan kuisioner, sedangkan data sekunder diperoleh dari instansi terkait dari Dinas Peternakan dan Kesehatan Hewan, Badan Pusat Statistik, Badan Pemerintahan Daerah dan data dari Perusahaan Mitra. Responden penelitian adalah peternak ayam broiler yang bermitra dengan PT. Karya Semangat Mandiri (KSM) berjumlah 12 orang dan peternak yang bermitra dengan Poultry Shop Torang berjumlah 10 orang. Selain dari peternak yaitu pimpinan PT. Karya Semangat Mandiri dan Poultry Shop Torang dan pihak mitra.

Beberapa definisi operasional yang digunakan selama penelitian ini adalah sebagai berikut:

1. Pola kerjasama meliputi bentuk kerja sama yang dilakukan oleh peternak ayam broiler dengan perusahaan PT. Karya Semangat Mandiri (KSM) dan Poultry Shop Torang dan ketentuan yang harus dilakukan kedua belah pihak

2. Pendapatan peternak mitra dihitung berdasarkan total (Penerimaan-Pengeluaran) dalam satu kali periode pemeliharaan

3. Penerimaan meliputi penjualan ternak ayam broiler pasca panen (Rupiah/Kg) dan penjualan kotoran ayam broiler/periode

4. Biaya meliputi biaya penyusutan kandang, peralatan kandang dan biaya sewa tanah / periode.

5. Biaya variabel meliputi DOC/box, pakan, obat-obatan, vaksin, listrik, tenaga kerja, kompor minyak, litter dan batu bara.

\section{Analisis data}

Analisis data yang digunakan adalah analisis data deskriptif kualitatif dan kuantitatif menggunakan rumus Soekartawi (2006):

$$
\mathrm{PD}=\mathrm{TR}-\mathrm{TC}
$$

Keterangan:

$\mathrm{PD}=$ Total pendapatan .

$\mathrm{TR}=$ Total penerimaan didapatkan dari penjualan ayam pasca panen ditambah dengan penjualan kotoran ayam.
$\mathrm{TC}=$ Total biaya didapatkan dari total keseluruhan biaya tetap ditambah dengan biaya variabel serta biaya penyusutan kandang. Untuk mencari biaya tetap kandang dan peralatan kandang dihitung dengan mempertimbangkan nilai awal, nilai sisa dan umur ekonomis dari kandang/peralatan tersebut.

\section{HASIL DAN PEMBAHASAN}

\section{Karakteristik responden}

Hasil penelitian karakteristik responden peternak kemitraan dibedakan berdasarkan usia, tingkat pendidikan, lama beternak, dan skala usaha. Karakteristik responden pada penelitian menunjukkan di Kecamatan Payakumbuh Timur, dapat dilihat pada Tabel 1.

Tabel 1 menunjukkan bahwa umur responden yang bermitra dengan Poultry Shop Torang seluruhnya berada diusia produktif yaitu umur 15-64 tahun, begitu juga peternak yang bermitra dengan PT. KSM seluruhnya juga berada diusia produktif yaitu 15-64 tahun. Kondisi ini menunjukkan bahwa seluruh responden berada dalam usia produktif dengan kemampuan fisik yang mendukung dalam mengelola usaha peternakan ayam ras pedaging. Hal ini sesuai dengan pendapat Jailani et al. (2013), yang menyatakan bahwa tenaga kerja yang umurnya masih muda kecenderungannya mempunyai fisik yang lebih kuat, sehingga diharapkan dapat bekerja keras dibandingkan dengan tenaga kerja yang umurnya lebih tua. Mahendra (2014) menambahkan analisis pengaruh pendidikan, upah, jenis kelamin, usia dan pengalaman kerja terhadap produktifitas tenaga kerja (studi kasus diindustri kecil tempe, Kota Semarang) menyatakan bahwa usia produktif akan meningkatkan motivasi bekerja untuk mendapatkan kehidupan lebih baik dengan mental lebih stabil. Lebih lanjut dijelaskan bahwa usia produktif ini berbeda dengan usia tidak produktif yang berumur dibawah 15 tahun yang belum stabil dari segi mental dan mudah goyah dalam menentukan prinsip yang akan berpengaruh terhadap usaha. Demikian juga dengan usia tidak produktif yang berada diatas 65 tahun bahwa motivasi bekerjanya untuk lebih sukses tidak terlalu tinggi berhubung karena usia tersebut telah matang dalam usaha dan keberlanjutan usaha tersebut.

Pendidikan peternak yang bermitra dengan Poultry Shop Torang 5 orang (50\%) 
Tabel 1. Karakteristik responden penelitian peternak yang bermitra dengan Poultry Shop Torang dan PT. Karya Semangat Mandiri di Kecamatan Payakumbuh Timur.

\begin{tabular}{|c|c|c|c|c|}
\hline Kategori & $\begin{array}{c}\text { Poultry Shop } \\
\text { Torang (Orang) }\end{array}$ & $\begin{array}{l}\text { Persentase } \\
\quad(\%)\end{array}$ & $\begin{array}{l}\text { PT. Karya } \\
\text { Semangat } \\
\text { Mandiri } \\
\text { (Orang) }\end{array}$ & $\begin{array}{l}\text { Persentase } \\
\quad(\%)\end{array}$ \\
\hline \multicolumn{5}{|l|}{ Umur (Tahun) } \\
\hline$\leq 14$ & - & - & - & - \\
\hline $15-64$ & 10 & 100 & 12 & 100 \\
\hline$\geq 65$ & - & - & - & - \\
\hline Jumlah & 10 & 100 & 12 & 100 \\
\hline \multicolumn{5}{|c|}{ Tingkat Pendidikan } \\
\hline SD & - & - & 2 & 16,67 \\
\hline SMP/Sederajat & 4 & 40 & 3 & 25 \\
\hline SMA/Sederajat & 5 & 50 & 6 & 50 \\
\hline $\begin{array}{l}\text { Perguruan } \\
\text { Tinggi }\end{array}$ & 1 & 10 & 1 & 8,33 \\
\hline Jumlah & 10 & 100 & 12 & 100 \\
\hline \multicolumn{5}{|c|}{ Pengalaman (Tahun) } \\
\hline $1-5$ & 2 & 20 & 9 & 75 \\
\hline $6-10$ & 4 & 40 & 2 & 16,67 \\
\hline $11-15$ & 3 & 30 & - & - \\
\hline$\geq 16$ & 1 & 10 & 1 & 8,33 \\
\hline Jumlah & 10 & 100 & 12 & 100 \\
\hline \multicolumn{5}{|c|}{ Skala usaha (Ekor) } \\
\hline $1000-3000$ & 10 & 100 & - & - \\
\hline $3100-6000$ & - & - & 8 & 66,67 \\
\hline $6100-9000$ & - & - & 3 & 25 \\
\hline $9100-12000$ & - & - & 1 & 8,33 \\
\hline Jumlah & 10 & 100 & 12 & 100 \\
\hline
\end{tabular}

berpendidikan SMA/sederajat, 4 orang (40\%) peternak berpendidikan SMP/sederajat dan 1 orang $(10 \%)$ peternak menempuh Perguruan Tinggi sedangkan pendidikan peternak yang bermitra dengan PT. KSM 6 orang (50\%) peternak berpendididkan SMA/sederajat, 3 orang $(25 \%)$ peternak menempuh pendidikan $\mathrm{SMP} /$ sederajat, 2 orang $(16,67 \%)$ peternak berpendidikan hanya sampai SD, dan 1 orang $(8,33 \%)$ peternak menempuh jenjang Perguruan Tinggi. Pendidikan terbanyak peternak yang bermitra dengan Poultry Shop Torang dan PT. KSM adalah SMA/sederajat, hal ini karena peternak plasma secara umum ingin langsung bekerja/berwirausaha dan kurang berminat melanjutkan pendidikan di perguruan tinggi. Tinggi atau rendahnya pendidikan peternak dapat mempengaruhi pola pikir peternak dan akan berdampak pada usaha yang sedang dijalaninya. Pendidikan memiliki peranan penting terhadap produktivitas usaha dan merupakan faktor pelancar pembangunan pertanian. Faktor-faktor yang mempengaruhi usaha ternaksapi potong di Kecamatan Tapanuli, Kabupaten Padang Sidempuan, Sumatera Utara menyatakan bahwa pendidikan yang tinggi akan peka terhadap perubahan dan terbuka akan informasi yang ada di sekitar. Peternak yang berpendidikan dan berpengetahuan tinggi akan cepat dan tepat dalam menerima serta melaksanakan inovasi baru. Faktor lain yang mempengaruhi adalah pengalaman (Nina, 2013). 
Pengalaman sangat mempengaruhi perilaku peternak. Semakin lama pengalaman peternak maka semakin tinggi pengetahuan yang didapat oleh peternak, dengan demikian keberhasilan peternak dengan pengalaman tinggiakansemakintinggi.Pengalaman peternak terbanyak yang bermitra dengan Poultry Shop Torang yaitu 6-10 tahun 40\% peternak, sedangkan pengalaman peternak terbanyak peternak yang bermitra dengan PT. KSM 1-5 tahun yaitu $75 \%$ peternak. Dalam berusaha tani memiliki peranan terhadap perolehan informasi sebanyak-banyaknya terutama terhadap inovasi. Pengukuran lama atau tidaknya pengalaman peternak diukur mulai sejak kapan peternak itu aktif secara mandiri mengusahakan usaha taninya (Simanjuntak, 2002).

Skala usaha peternak yang bermitra dengan Poultry Shop Torang 10 orang (100\%) berada diantara 1000-3000 ekor, sedangkan peternak yang bermitra dengan PT. KSM mempunyai skala usaha 3100-6000 ekor yaitu 8 orang $(66,67 \%)$ peternak, $6100-9000$ ekor 3 orang (25\%) peternak dan 9100-12000 ekor 1 orang $(8,33 \%)$ peternak. Dari data tersebut dapat dilihat bahwa peternak yang bermitra dengan Poultry Shop Torang semuanya berskala usaha dibawah 3500 ekor sesuai dengan latar belakang penelitian yang menyatakan bahwa peternak yang mempunyai skala usaha dibawah 3500 ekor dapat bermitra dengan Poultry Shop Torang, sedangkan peternak yang bermitra dengan PT. KSM mempunyai skala usaha dimulai dari 3500 ekor hingga 12000 ekor, ini sesuai dengan persyaratan peternak yang dapat bermitra dengan PT. KSM harus mempunyai skala usaha peternakan ayam broiler $\geq 3500$ ekor.

\section{Pola kerjasama}

Bentuk kerjasama yang dilakukan oleh peternak yang bermitra dengan Poultry Shop torang dan bentuk kemitraan yang dilakukan peternak dengan PT. KSM dapat dilihat pada Tabel 2.

Tabel 2. Pola kemitraan yang dilakukan peternak dengan Poultry Shop Torang dan PT. Karya Semangat Mandiri di Kecamatan Payakumbuh Timur

\begin{tabular}{ll}
\hline Jenis Kemitraan & Pola Kemitraan \\
\hline Poultry Shop Torang & Pola bagi hasil \\
PT. Karya Semangat & Pola inti plasma \\
Mandiri & \\
\hline
\end{tabular}

Tabel 2 menunjukkan bahwa pola kemitraan peternak dengan Poultry Shop Torang menggunakan pola kemitraan bagi hasil, sedangkan peternak dengan PT. KSM menggunakan pola inti plasma. Pola bagi hasil yang disepakati oleh peternak dan Poultry Shop Torang dimana keuntungan dapat dibagi dua antara peternak dan Poultry Shop yaitu peternak $50 \%$ danuntukPoultry Shop Torang $50 \%$. Menurut Permentan nomor 13 (2017) ada beberapa bentuk kemitraan yaitu pola inti plasma, pola bagi hasil, pola sewa, pola perdagangan umum dan pola subkontrak, pengertian pola bagi hasil adalah hubungan kemitraan antar peternak atau antara peternak sebagai pelaksana yang menjalankan usaha budidaya yang dibiayai atau dimiliki oleh perusahaan peternakan atau perusahaan dibidang lain.

Pola kemitraan peternak pada PT. KSM adalah pola kemitraan inti plasma, dalam kerjasama kemitraan inti plasma pihak pertama/ perusahaan sebagai inti dan pihak kedua/ peternak sebagai plasma. Menurut Permentan nomor 13 (2017) pola inti plasma adalah hubungan kemitraan antara kelompok mitra dengan perusahaan mitra yang didalamnya perusahaan bertindaksebagai inti dan kelompok mitra sebagai plasma dengan tanggung jawab masing-masing pihak adalah sebagai berikut :

1. Pihak pertama selaku Inti berperan dan bertanggung jawab untuk:

a. Memberikan bimbingan teknis pemeliharaan atau budidaya ayam broiler, bimbingan manajemen dan administrasi usaha, dan bantuan pemasaran hasil budidaya/petemakan, bantuan manajemen keuangan, antara lain dengan cara menugaskan seorang petugas Technical Service (TS) untuk sewaktu-waktu mengajar dan membimbing peternak.

b. Menyediakan atau memasok, kepada pihak kedua, sarana produksi peternakan, yang meliputi : pakan, anak ayam umur sehari (Day Old Chicks/DOC) dan obatobatan (selanjutnya disebut sapronak), yang jenis, jumlah, jadwal dan syaratsyarat pemasokannya akan ditentukan dari waktu kewaktu oleh pihak pertama.

c. Membantu mengelola penggunaan sapronak, termasuk apabila perlu memediasi pengalihan sapronak yang tidak digunakan kepada pihak lain, baik melalui mekanisme jual beli, tukar menukar ataupun dengan cara lainnya.

d. Membeli ayam hasil produksi/budidaya 
pihak kedua menurut syarat-syarat dan ketentuan-ketentuan yang akan disepakati dan menjadi bagian yang tidak terpisahkan dari perjanjian.

e. Membantu pihak kedua dalam administrasi keuangan dan pengelolaan hutang piutang pihak kedua.

2. Pihak kedua selaku plasma berperan dan bertanggung jawab untuk:

a. Dengan biaya sendiri menyediakan lahan peternakan.

b. Membangun kandang ayam dan menyediakan perlengkapan/peralatannya sesuai standar yang ditetapkan oleh pihak pertama.

c. Menyediakan sendiri tenaga kerja.

d. Melaksanakan budidaya atau pemeliharaan ayam menurut petunjuk-petunjuk dan tata cara budidaya/pemeliharaan ayam menuntut petunjuk-petunjuk dan tata cara ayam yang ditetapkan oleh pihak pertama.

e. Menjaga mutu/kualitas ayam, antara lain dengan cara menggunakan sapronak yang dipasok atau yang direkomendasi oleh pihak pertama menurut tatacara serta jumlah yang ditetapkan oleh pihak pertama.

f. Menjalankan prosedur administrasi dan tata cara panen yang ditetapkan.

g. Menjaga keamanan kandang dan sapronak.

h. Menjalankan biosecurity (sistem pengamanan hayati) yang ketat, termasuk dengan cara tidak mencampur ayam dengan ayam dari luar kandang/farm dan tidak memasukan pakan yang tidak direkomendasikan ke kandang/farm.

i. Tidak menambah ayam dikandang sehingga melebihi kapasitas yang diperbolehkan.

j. Tidak menggunakan pakan yang tidak direkomendasikan.

k. Melapor secara periodik perkembangan budidaya ayam kepada pihak pertama melalui media laporan pemeliharaan ayam broiler yang diisi lengkap dan benar sesuai fakta terbaru.

1. Menjual ayam hasil budidaya kepada pihak pertama menurut syarat-syarat dan ketentuan-ketentuan yang akan disepakati dan menjadi bagian yang tidak terpisahkan dari perjanjian.

Peternak yang bermitra dengan Poultry Shop Torang dan PT. KSM harus menjalankan ketentuan yang sudah disepakati, jika peternak tidak menjalankan ketentuan tersebut maka pihak Poultry Shop Torang atau pihak PT. Karya SemangatMandiridapatmemutuskankemitraan yang sedang dijalani secara sepihak. Ketentuan yang harus dilakukan oleh peternak dan Poultry Shop Torang dan PT. Karya Semangat Mandiri dapat dilihat pada Tabel 3.

Pada Tabel 3 dapat dilihat persamaan ketentuan yang harus dilakukan oleh peternak yang bermitra dengan Poultry Shop Torang dan PT. KSM terdapat pada poin 2, 5 dan 6 yaitu kandang dan peralatan disediakan oleh peternak, DOC, pakan, obat - obatan, vaksin, dan pemasaran hasil produksi dilakukan oleh pihak mitra, sedangkan perbedaan ketentuannya terdapat pada poin 1, 3, 4, 7, 8, 9dan 10.

Ketentuan yang harus dilakukan oleh peternak terhadap perusahaan mitra dan kewajiban perusaahan terhadap peternak. Perjanjian kerjasama yang dilakukan oleh Poultry Shop Torang dengan peternak tidak dilakukan dengan cara tertulis karena pihak Poultry Shop tidak mau terlalu terikat dengan peternak dan jika terjadi kecurangan dilakukan oleh peternak Poultry Shop bisa memutuskan kerjasama secara sepihak. Perjanjian kerjasama yang dilakukan peternak PT. KSM adalah dengan menggunakan perjanjian tertulis yang menggunakan materai tempel yang disepakati oleh kedua pihak. Hal ini bertujuan agar peternak atau perusahaan tidak melakukan kecurangan dan harga yang dibayarkan peternak atau perusahaan sudah terlampir di dalam perjanjian tersebut, dari ketentuan kerjasama diatas peternak yang bermitra dengan PT. Karya Semangat Mandiri lebih diuntungkan dari pada peternak yang bermitra dengan Poultry Shop Torang.

Kandang dan peralatan kandang peternak yang bermitra dengan Poultry Shop Torang disediakan oleh peternak dan dibiayai sendiri oleh peternak. Dalam hal ini peternak bisa membeli peralatan kandang kepada Poultry Shop Torang atau ketempat lain. Peternak yang bermitra dengan PT. Karya Semangat Mandiri, kandang dan peralatan kandang juga disediakan peternak dan dibiayai oleh peternak, dalam hal ini peternak juga bisa membeli langsung kepada perusahaan, namun peternak bisa membayar peralatan kandang secara kredit kepada perusahaan.

Peternak yang bermitra dengan Poultry Shop Torang tidak memberikan uang jaminan kepada Poultry Shop Torang, sedangkan peternak yang bemitra dengan PT. Karya Semangat Mandiri memberikan uang jaminan 
Tabel 3. Ketentuan yang harus dilakukan kedua belah pihak dengan Poultry Shop Torang dan PT. Karya Semangat Mandiri

\begin{tabular}{|c|c|c|}
\hline No. & Poultry Shop Torang & PT. Karya Semangat Mandiri (KSM) \\
\hline 1. & Perjanjian secara tidak tertulis & Perjanjian kerjasama secara tertulis \\
\hline 2. & $\begin{array}{l}\text { Kandang dan peralatan kandang } \\
\text { disediakan oleh peternak }\end{array}$ & $\begin{array}{l}\text { Kandang dan peralatan kandang } \\
\text { disediakan oleh peternak }\end{array}$ \\
\hline 3. & Tidak ada uang jaminan & $\begin{array}{l}\text { Peternak memberikan uang jaminan } \\
\text { dengan nilai Rp 3000/Ekor }\end{array}$ \\
\hline 4. & $\begin{array}{l}\text { Menggunakan pola kemitraan bagi } \\
\text { hasil }\end{array}$ & $\begin{array}{l}\text { Menggunakan pola kemitraan inti } \\
\text { plasma }\end{array}$ \\
\hline 5. & $\begin{array}{l}\text { DOC, Pakan, obat - obatan dan } \\
\text { vaksin disediakan Poultry Shop }\end{array}$ & $\begin{array}{l}\text { DOC, Pakan, obat - obatan dan vaksin } \\
\text { disediakan perusahaan }\end{array}$ \\
\hline 6. & $\begin{array}{l}\text { Pemasaran seluruhnya dilakukan oleh } \\
\text { pihak Poultry Shop Torang }\end{array}$ & $\begin{array}{l}\text { Pemasaran seluruhnya dilakukan oleh } \\
\text { pihak PT. Karya Semangat Mandiri }\end{array}$ \\
\hline 7. & $\begin{array}{l}\text { Kegagalan pemeliharaan atau panen } \\
\text { ditanggung secara sepihak kepada } \\
\text { peternak, namun Poultry Shop Tetap } \\
\text { memberikan uang pesangon sebesar } \\
\text { Rp } 700.000\end{array}$ & $\begin{array}{l}\text { Resiko kegagalan pemeliharaan dan } \\
\text { panen akan mendapat keringanan oleh } \\
\text { perusahaan berupa uang atas biaya } \\
\text { persiapan kandang sebesar Rp } 400 \\
\text { dalam } 1 \mathrm{~kg} \text { ayam yang dijual. }\end{array}$ \\
\hline 8. & $\begin{array}{l}\text { Semua biaya yang dikeluarkan } \\
\text { (ditanggung) oleh perusahaan selama } \\
\text { pemeliharaan dibayar setelah panen }\end{array}$ & $\begin{array}{l}\text { Hasil penjualan dan tambahan bonus } \\
\text { secara lansung akan mendapat } \\
\text { potongan berdasarkan semua biaya }\end{array}$ \\
\hline 9. & $\begin{array}{l}\text { Bimbingan dilakukan oleh pengawas } \\
\text { yang kurang profesional hanya } \\
\text { tamatan SMK peternakan kandang } \\
\text { yang disediakan oleh Poultry Shop. }\end{array}$ & $\begin{array}{l}\text { Disediakan Technical Service (TS) yang } \\
\text { profesional tamatan S1 oleh perusahaan } \\
\text { untuk memberi bimbingan kepada } \\
\text { peternak. }\end{array}$ \\
\hline 10. & $\begin{array}{l}\text { Harga penjualan berubah-ubah setiap } \\
\text { waktu karena tergantung kepada } \\
\text { harga ayam dipasaran. }\end{array}$ & $\begin{array}{l}\text { Harga penjualan ayam tersebut } \\
\text { dihargai sesuai dengan harga yg ada } \\
\text { pada perjanjian kerjasama. }\end{array}$ \\
\hline
\end{tabular}

kepada PT. Karya Semangat Mandiri agar peternak tidak melakukan kecurangan terhadap PT. KSM dan jika terjadi kerugian uang jaminan tersebut akan dipotong langsung oleh pihak perusahaan, jika peternak memutuskan kemitraan dengan PT. KSM maka uang jaminan tersebut akan dikembalikan kepada peternak, dalam ketentuan ini peternak yang bermitra dengan Poultry Shop Torang lebih diuntungkan dibandingkan dengan peternak yang bermitra dengan PT. KSM.

Pola kemitraan antara peternak dengan Poultry Shop Torang menggunakan pola kemitraan bagi hasil. Pola bagi hasil yang diterapkan adalah keuntungan penjualan ayam broiler dibagi sama rata antara peternak dan perusahaan yaitu untuk peternak $50 \%$ dan untuk Poultry Shop Torang 50\%, sedangkan pola kemitraan yang dilakukan oleh peternak yang bermitra dengan PT. KSM menggunakan pola inti plasma yang dimana semua harga input dan output sudah tertulis dalam perjanjian. Peternak yang bermitra dengan Poultry Shop Torang doc, pakan, obat dan vaksin disediakan oleh Poultry Shop dan pembayaran dilakukan oleh peternak pada saat ayam panen hal ini juga berlaku dengan peternak yang bermitra dengan PT. KSM, dalam ketentuan kerjasama ini peternak yang bermitra dengan PT. KSM lebih diuntungkan dibandingkan peternak yang bermitra dengan Poultry Shop Torang.Ditinjau dari segi pemasaran ayam broiler pada saat panen, pada peternak yang bermitra dengan Poultry Shop Torang pemasaran dilakukan sepenuhnya oleh pihak Poultry Shop begitu juga dengan peternak yang bermitra dengan PT. KSM.

Jika terjadi kegagalan saat pemeliharaan pada peternak yang bermitra dengan Poultry Shop Torang kerugian ditanggung sendiri oleh peternak, namun pihak Poultry Shop tetap memberikan uang pemeliharaan sebesar $\mathrm{Rp}$ 700.000 kepada peternak jika pendapatan peternak dibawah $\mathrm{Rp} 400.000$ agar peternak tetap mau bermitra dengan Poultry Shop Torang. Sedangkan peternak yang bermitra dengan PT. Karya Semangat Mandiri kerugian pada saat pemeliharaan juga ditanggung sendiri oleh peternak, namun peternak dapat keringanan dari pihak perusahaan karena diberi uang atas 
persiapan kandang sebesar Rp 400 dalam 1 $\mathrm{kg}$ ayam yang terjual agar peternak tetap mau bermitra dengan PT. KSM. Ketentuan kerjasama ini peternak yang bermitra dengan PT. KSM lebih diuntungkan dibandingkan peternak yang bermitra dengan Poultry Shop Torang.

Peternak yang bermitra dengan Poultry Shop Torang semua biaya produksi yang di keluarkan ditanggung oleh pihak Poultry Shop Torang selama pemeliharaan dan dibayar setelah panen, sedangkan peternak yang bermitra dengan PT. KSM hasil penjualan dan tambahan bonus secara langsung akan mendapat potongan berdasarkan semua biaya, dalam ketentuan kerjasama ini peternak yang bermitra dengan PT. KSM lebih diuntungkan dibandingkan peternak yang bermitra dengan Poultry Shop Torang.

Peternak yang bermitra dengan Poultry Shop Torang disediakan pengawas kandang dari Poultry Shop Torang untuk melakukan pengontrolan terhadap ayam broiler dan memberikan bimbingan kepada peternak dan peternak bisa bertanya langsung kepada pengawas.Hal ini dapat berupa pemberian vaksin dan obat serta cara penanganan penyakit yang terjadi pada ayam broiler tetapi pengawas yang disediakan oleh Poultry Shop Torang belum terlalu profesional karena hanya tamatan SMK peternakan. Peternak yang bermitra dengan PT. KSM peternak disediakan Technical Service (TS) yang bekerja secara profesional karena TS yang disediakan tamatan S1 peternakan yang lebih paham di bidang peternakan. Technical Service tersebut bertugas untuk memberikan bimbingan manajemen dan administrasi usaha, dan bantuan pemasaran hasil budidaya/ peternakan, bantuan manajemen keuangan, dalam ketentuan kerjasama ini peternak yang bermitra dengan PT. KSM lebih diuntungkan dibandingkan peternak yang bermitra dengan Poultry Shop Torang.

Harga penjualan ayam bagi peternak yang bermitra dengan Poultry Shop Torang sesuai dengan harga pasar, jika harga ayam dipasar tinggi maka penerimaan peternak juga tinggi, demikian sebaliknya jika harga ayam sedang rendah maka penerimaan peternak juga rendah. Sedangkan peternak yang bermitra dengan PT.KSM, harga penjualan ayam sudah ditetapkan didalam perjanjian, berdasarkan ketentuan kerjasama yang harus dilakukan oleh kedua belah pihak antara peternak dan perusahaan, sehingga peternak yang bermitra dengan PT. KSM lebih diuntungkan dari pada peternak yang bermitra dengan Poultry Shop Torang.

\section{Pendapatan}

Laporan rugi laba peternak yang bermitra dengan Poultry Shop Torang dan PT. Karya Semangat Mandiri dapat dilihat pada Tabel 4.

\section{Penerimaan}

Tabel 4 menunjukkan rata-rata penerimaan peternak yang bermitra dengan Poultry Shop Torang adalah Rp 36.881.192,48 dengan ratarata skala usaha ayam yang dipelihara adalah 1.670 ekor dan rata-rata mortalitas adalah $12 \%$. Penerimaan didapat dari hasil penjualan ayam saja sementara kotoran ayam tidak dijual hanya dimanfaatkan saja oleh peternak sebagai pupuk bagi tanaman dikebun sendiri atau diberikan kepada tetangga yang membutuhkan pupuk organik, ada yang hanya dibuang saja oleh peternak tanpa dimanfaatkan serta tidak ada penambahan bonus dari Feed Conversion Rasio (FCR) dari Poultry Shop Torang. Penerimaan peternak dalam 1.000 ekor ayam broiler adalah adalah Rp 22.002.859,13 dan penerimaan peternak dalam $1 \mathrm{~kg}$ ayam adalah $\mathrm{Rp}$ 18.647,31.

Rata-rata penerimaan peternak yang bermitra dengan PT. KSM adalah Rp 175.928.252,58 dengan rata-rata skala usaha 5.958 ekor dan rata-rata mortalitas adalah $4,1 \%$ penerimaan ini didapatkan dari tiga sumber yaitu penjualan ayam broiler sebanyak $\mathrm{Rp}$ 173.534.143,70, penerimaan dari penjualan kotoran adalah $\mathrm{Rp} 1.163 .333,33$ dan penerimaan dari tambahan bonus Feed Conversion Rasio (FCR) adalah $\mathrm{Rp} 1.230 .775,55$, penerimaan peternak dalam 1.000 ekor adalah Rp 30.213.129,31 dan penerimaan peternak dalam $1 \mathrm{~kg}$ ayam adalah Rp 17.041,04.

Penerimaan tertinggi peternak yang bermitra dengan Poultry Shop Torang adalah Rp 57.890.880,8, total ayam yang keluar adalah 1.520 ekor dengan total berat ayam keseluruhan adalah $2.826,2 \mathrm{~kg}$, harga ayam pada saat panen adalah Rp 20.484. Penerimaan terendah peternak adalah $\mathrm{Rp} 20.673 .000$, total ayam yang keluar adalah 867 ekor dan total berat ayam adalah $1.148,5 \mathrm{~kg}$ dengan harga saat panen adalah Rp 18.000, sedangkan penerimaan tertinggi peternak yang bermitra dengan PT. Karya Semangat Mandiri adalah Rp 403.299.981,10 dengan jumlah total ayam yang keluar adalah 11.500 ekor mempunyai total berat $23.571,01 \mathrm{~kg}$ dan harga ayam adalah Rp 16.970.Penerimaan peternak yang terendah adalah Rp 95.313.255,46 
Tabel 4. Laporan rugi laba peternak yang bermitra dengan Poultry Shop Torang dan PT. Karya Semangat Mandiri.

\begin{tabular}{|c|c|c|c|c|}
\hline Laporan rugi laba & $\begin{array}{c}\text { Poultry Shop } \\
\text { Torang (Orang) }\end{array}$ & $\begin{array}{c}\text { Persentase } \\
\quad(\%)\end{array}$ & $\begin{array}{c}\text { PT. Karya } \\
\text { Semangat Mandiri } \\
\text { (Orang) }\end{array}$ & $\begin{array}{c}\text { Persentase } \\
(\%)\end{array}$ \\
\hline \multicolumn{5}{|l|}{ Penerimaan } \\
\hline Penjualan ayam & $36.881 .192,48$ & & $173.534 .143,70$ & \\
\hline Penjualan kotoran & - & 100 & $1.163 .333,33$ & \\
\hline Bonus FCR & - & & $1.230 .775,55$ & \\
\hline Total penerimaan & $36.881 .192,48$ & & $175.928 .252,58$ & \\
\hline \multicolumn{5}{|l|}{ Biaya tetap } \\
\hline $\begin{array}{l}\text { Penyusutan kandang } \\
\text { dan peralatan }\end{array}$ & $345.135,04$ & 1,01 & $1.646 .195,45$ & 1,04 \\
\hline Total biaya tetap & $345.135,04$ & 1,01 & $1.646 .195,45$ & 1.04 \\
\hline \multicolumn{5}{|l|}{ Biaya variabel } \\
\hline DOC & $9.528 .500,00$ & 28,1 & $36.441 .666,67$ & 23,4 \\
\hline Pakan & 23.268.150,00 & 68,8 & $114.105 .433,83$ & 73,5 \\
\hline Obat dan vaksin & $688.600,00$ & 2 & 2.915.910,91 & 1,87 \\
\hline Listrik & $140.000,00$ & 0,41 & $350.000,00$ & 0,22 \\
\hline Upah karyawan & - & & $2.500 .000,00$ & 1,61 \\
\hline Biaya bahan bakar & $283.333,33$ & 0,83 & $1.462 .583,33$ & 0,94 \\
\hline Kompor minyak & $140.800,00$ & 0,41 & - & \\
\hline Batu bara & $75.000,00$ & 0,22 & - & \\
\hline Total biaya variabel & $34.124 .383,33$ & 100 & $157.775 .594,74$ & 100 \\
\hline Total biaya & $34.469 .518,37$ & & 159.421.790,19 & \\
\hline Pendapatan & 2.732.907,44 & & $16.356 .179,42$ & \\
\hline Penerimaan 1.000 ekor & $22.002 .859,13$ & & $30.213 .129,31$ & \\
\hline Penerimaan $1 \mathrm{~kg}$ ayam & $18.647,31$ & & $17.041,04$ & \\
\hline Biaya dalam 1.000 ekor & $20.448 .074,88$ & & $26.332 .180,42$ & \\
\hline Biaya dalam $1 \mathrm{~kg}$ ayam & $17.265,53$ & & $15.406,30$ & \\
\hline Pendapatan 1.000 ekor & $1.636 .471,52$ & & $2.745 .094,59$ & \\
\hline Pendapatan ekor dibagi 2 & $818.235,76$ & & & \\
\hline Pendapatan $1 \mathrm{~kg}$ ayam & $1.381,77$ & & $1.606,18$ & \\
\hline Pendapatan dibagi 2 & 690,88 & & & \\
\hline
\end{tabular}

penerimaan peternak rendah disebabkan oleh ayam yang keluar pada saat panen hanya 3.450 dan total berat ayam adalah 5.597,88 $\mathrm{kg}$ serta harga setiap kilogram ayam adalah Rp 16.886, 67.

Perbandingan penerimaan peternak yang bermitra dengan Poultry Shop Torang dan PT. KSM adalahrata-rata penerimaan peternak yang bermitra dengan PT. KSM lebih tinggi dibandingkan dengan rata-rata penerimaan peternak yang bermitra dengan Poultry Shop
Torang. Hal ini disebabkan oleh peternak yang bermitra dengan PT. KSM pemeliharaan ayam broiler terkelola dengan baik sehingga rata-rata mortalitasnya rendah yaitu hanya $4,1 \%$ dan peternak mendapatkan tambahan penerimaan dari penjualan kotoran ayam serta bonus Feed Conversion Ratio (FCR) dari perusahaan, sedangkan penerimaan Poultry Shop Torang pemeliharaan ayam broiler belum terkelola dengan baik sehingga tingkat mortalitasnya lebih tinggi yaitu $12 \%$ dan penerimaan didapat 
hanya dari penjualan ayam saja. Heriyatno (2009)menyatakan bahwa penilaian besarnya penerimaan yang dihasilkan dari setiap uang yang dikeluarkan dalam suatu kegiatan usaha tani dapat digunakan perhitungan rasio penerimaan atas biaya ( $\mathrm{R} / \mathrm{C}$ ratio).

\section{Biaya tetap}

Rata-rata biaya tetap yang dikeluarkan oleh peternak yang bermitra dengan Poultry Shop Torang adalah sebanyak Rp 345.135,04. Biaya tetap yang dikeluarkan oleh peternak didapat dari hasil biaya penyusutan kandang dan peralatan yang dikeluarkan oleh peternak dalam satu kali periode pemeliharaan. Biaya penyusutan didapatkan dari nilai awal dikurangi dengan nilai sisa dan seterusnya dibagi dengan umur ekonomis kandang atau peralatan kandang. Biaya tetap tetinggi yang dikeluarkan peternak dalam satu kali periode pemeliharaan adalah $\operatorname{Rp} 807.252,43$ dan biaya tetap yang terendah dikeluarkan oleh peternak dalam satu kali periode adalah Rp 144.277,06.

Rata-rata biaya tetap yang harus dikeluarkan oleh peternak yang bermitra dengan PT. KSM adalah sebesar Rp.1.646.195,45 biaya tetap tertinggi yang dikeluarkan oleh peternak adalah sebesar Rp 2.715.065,98, sementara biaya tetap terendah yang dikeluarkan oleh peternak adalah sebanyak Rp 962.751,90. Besar atau kecilnya biaya tetap yang dikeluarkan oleh peternak tergantung kepada besarnya nilai awal kandang dan peralatan kandang serta umur ekonomis pemakaian kandang dan peralatan sangat mempengaruhi besar biaya tetap yang dikeluarkan oleh peternak.

Perbandingan pengeluaran biaya tetap peternak yang bermitra dengan dengan Poultry Shop Torang dan PT. KSM dimana biaya tetap yang terbesar dikeluarkan oleh peternak yang bermitra dengan PT. KSM karena nilai awal kandang, peralatan kandang yang tinggi dan kandang ayam broiler peternak yang bermitra dengan perusahaan harus memenuhi standar perusahaan seperti kandang harus berbentuk kandang panggung, akses untuk air minum mudah didapatkan atap kandang berupa asbes bukan seng, karena dikhawatirkan ayam yang akan dikandangkan akan mengalami stress. Hardjosworo dan Rukmiasih (2000) menyatakan bahwa ukuran luas kandang tergantung dari kepadatan jumlah populasi ternak yang dipelihara. Luas yang cukup bagi ayam untuk ruang geraknya maka tidak akan terjadi saling patuk dan stress. Hal ini sesuai dengan pendapat
Yunus (2009) bahwa biaya tetap terdiri atas biaya penyusutan dari pembuatan kandang dan pengadaan peralatan serta pajak yang besarnya tidak tergantung pada besar kecilnya skala usaha.

\section{Biaya variabel}

Biaya variabel yang dikeluarkan oleh peternak yang bermitra dengan Poultry Shop Torang adalah Rp. 33.803.150, dengan rata-rata biaya variabel tertinggi adalah biaya pakan karena $68,8 \%$ dari total biaya adalah biaya pakan yang berjumlah Rp 23.268.150.

Rata-rata biaya variabel yang dikeluarkan oleh peternak yang bermitra dengan PT. KSM adalah sebanyak Rp 155.240.935,5, biaya variabel tetinggi yang dikeluarkan peternak adalah biaya pakan karena $73,5 \%$ dari total biaya adalah biaya pakan yang berjumlah Rp 114.105.433,83.Kondisi ini sama dengan peternak yang bermitra dengan Poultry Shop Torang karena tujuan pemeliharaan ayam broiler adalah untuk mendapatkan daging maka pakan yang diberikan juga harus optimal. Maulana et al. (2014) menyatakan bahwa salah satu faktor yang berperan penting dalam mempengaruhi laju pertumbuhan adalah konsumsi ransum. Yunus et al. (2007) menyatakan bahwa 70-75\% dari total biaya produksi adalah biaya pakan.

Biaya variabel yang tertinggi dikeluarkan oleh peternak yang bermitra dengan Poultry Shop Torang adalah Rp 55.762.000 dan ayam broiler yang dipelihara adalah 2.500 ekor, sementara biaya variabel terendah yang dikeluarkan oleh peternak adalah $\mathrm{Rp} 20.706 .000$ dengan total ayam broiler yang dipelihara adalah sebanyak 1.000 ekor.Sedangkan biaya variabel tetinggi peternak yang bermitra dengan PT. KSM adalah Rp349.000.000 dengan total ayam yang dipelihara adalah 12.000 ekor dan biaya variabel yang terendah adalah sebanyak Rp 87.150.000 dengan jumlah ayam broiler yang dipelihara adalah 3.500 ekor. Tinggi atau rendahnya biaya variabel yang dikeluarkan oleh peternak yang bermitra dengan PT. KSM disebabkan oleh lama pemeliharaan ayam per periode.

Biaya variabel yang dikeluarkan oleh peternak yang bermitra dengan PT. KSM lebih besar dari pada peternak yang bermitra dengan Poultry Shop Torang, peternak yang bermitra dengan Poultry Shop Torang tidak ada yang menggunakan karyawan. Pemeliharaan dilakukan sendiri oleh peternak karena skala usahanya kecil, sedangkan peternak yang bermitra dengan PT. KSM ada yang 
menggunakan karyawan karena skala usahanya besar.

Peternak yang bermitra Poultri Shop Torang menggunakan kompor minyak dan batu bara untuk menghangatkan ayam broiler yang biayanya labih rendah, sedangkan peternak yang bermitra dengan PT. KSM hanya menggunakan gasolex untuk menghangatkan ayam broiler sehingga biaya yang dikeluarkan lebih besar. Soekartawi (2006) menyatakan biaya variabel adalah biaya yang berubah-ubah mengikuti besar kecilnya volume produksi, misalnya pengeluaran untuk sarana produksi biaya pengadaan bibit, pupuk, obat-obatan, pakan dan lain sebagainya.

Rata-rata total biaya yang dikeluarkan oleh peternak yang bermitra dengan Poultry Shop Torang dalam 1.000 ekor ayam adalah Rp 20.448.074,88 dan total biaya yang dikeluarkan peternak dalam $1 \mathrm{~kg}$ ayam adalah Rp 17.265,53, sedangkan rata-rata biaya yang dikeluarkan peternak yang bermitra dengan PT. KSM dalam 1.000 ekor ayam adalah $\mathrm{Rp} 26.332 .180,42$ dan rata-rata total biaya yang dikeluarkan peternak dalam $1 \mathrm{~kg}$ ayam adalah Rp 15.406,30.

\section{Pendapatan}

Rata-rata pendapatan peternak yang bermitra dengan Poultry Shop Torang dalam 1.000 ekor ayam broiler adalah Rp 1.636.471,52 setelah dibagi dua adalah $\operatorname{Rp} 818.235,76$ dan rata-rata pendapatan peternak dalam $1 \mathrm{~kg}$ ayam adalah $\mathrm{Rp} 1.381,77$ dan setelah dibagi dua adalah Rp 690,88. Pendapatan peternak diperoleh dari hasil penerimaan oleh peternak dikurangi dengan total seluruh biaya yang dikeluarkan.. Pendapatan tertinggi peternak yang bermitra dengan Poultry Shop Torang adalah Rp 8.426.361,37 dan ada peternak yang mengalami kerugian hingga $\mathrm{Rp}$ 2.321.527,62 yang disebabkan oleh banyaknya ayam yang mati dalam pemeliharaan.

Rata-rata pendapatan peternak yang bermitra dengan PT. KSM dalam 1.000 ekor ayam broiler adalah sebanyak Rp 2.745.094,59 dan rata-rata pendapatan peternak dalam $1 \mathrm{~kg}$ ayam adalah 1.606,18. Pendapatan tertinggi peternak adalah sebanyak $\mathrm{Rp} 52.429 .680,83$ dan ada peternak yang mengalami kerugian hingga Rp 3.257.922,32 yang disebabkan mortalitas yang tinggi akibat stress.

Pendapatan tertinggi diperoleh oleh peternak yang bermitra dengan PT. KSM karena ada penambahan bonus FCR dari perusahaan, dan manajemen pemeliharaan ayam broiler sudah terkelola dengan baik sehingga tingkat mortalitas rendah, keuntungan yang diperoleh atas penjualan ayam pada saat panen tidak dibagi dua antara peternak dan perusahaan (Ratnasari et al., 2015). Peternak yang bermitra dengan Poultry Shop Torang manajemen pemeliharaan ayam broiler belum terkelola dengan baik sehingga tingkat mortalitas rendah dan tidak ada penambahan bonus FCR dalam penerimaan serta kentungan yang di dapat pada saat ayam dipanen dibagi dua antara peternak dengan Poultry Shop Torang. Windarsari et al. (2012) menyatakan bahwa pendapatan merupakan selisih antara penerimaan total dengan biaya pengeluaran. Untuk menganalisis pendapatan diperlukan dua keterangan pokok, yaitu keadaan pengeluaran dan penerimaan dalam jangka waktu tertentu. Siregar (2005), menyatakan bahwa pendapatan merupakan selisih dari penerimaan dan biaya produksi atau pengeluaran.

Menurut Fadhli (2014) perbedaan pendapatan peternakan ayam broiler yang bermitra dengan PT. PKP (Prima Karya Persada) dan UD. Harco di Kecamatan Bajeng Kabupaten Gowa diperolehn bahwa peternak yang bermitra dengan perusahaan PT. PKP lebih untung dibandingkan peternak yang bermitra dengan Poultri Shop UD. Harco karena dilihat dari skala usaha yang dilakukan oleh peternak. Nizam (2013) juga menambahkan analisa pendapatan peternak ayam broiler pada pola kemitraan yang berbeda di Kecamatan Tellusiattinge Kabupaten Bone didapatkan bahwa pendapatan peternak yang bermitra dengan perusahaan cenderung lebih tinggi dibandingkan pendapatan peternak yang bermitra dengan kemitraan perseorangan.

\section{KESIMPULAN DAN SARAN}

\section{Kesimpulan}

Dari hasil dan pembahasan yang telah dilakukan maka dapat ditarik kesimpulan sebagai berikut :

1. Pola kerjasama antara peternak dengan Poultry Shop Torang menggunakan pola kemitraan bagi hasil yaitu total pendapatan dibagi dua, dari ketentuan kerjasama yang harus dilakukan oleh kedua belah pihak antara peternak dan perusahaan, peternak yang bermitra dengan PT. KSM lebih diuntungkan dari pada peternak yang bermitra dengan Poultry Shop Torang, dikarenakan peternak yang bermitra dengan PT. KSM ada penambahan bonus FCR dari perusa- 
haan dan manajemen pemeliharaan ayam broiler yang terstruktur dengan baik sehingga tingkat mortalitas rendah sedangkan yang didapat atas penjualan ayam pada saat panen tidak dibagi dua antara peternak dan perusahaan

2. Pendapatan peternak yang bermitra dengan PT. KSM lebih tinggi dibandingkan pendapatan peternak yang bermitra dengan Poultry Shop Torang. Pendapatan peternak yang bermitra dengan PT. KSM adalah sebanyak Rp 2.745.094,59 dalam dalam 1000 ekor ayam broiler, sedangkan pendapatan peternak yang bermitra dengan Poultry Shop Torang adalah sebanyak $\operatorname{Rp} 1.636,471,52$ dalam 1000 ayam broiler.

\section{Saran}

Peternak sebaiknya bermitra dengan PT. KSM untuk mendapatkan keuntungan yang lebih tinggi dan perjanjian kerjasama dilakukan secara jelas.

\section{DAFTAR PUSTAKA}

Badan Pusat Statistik Indonesia. 2017. Statistik Indonesia . CV. Graphic Dwipa, Indonesia.

Badan Pusat Statistik Kota Payakumbuh. 2017. Kota Payakumbuh Dalam Angka. CV. Graphic Dwipa, Kota Payakumbuh.

Badan Pusat Statistik Sumatera Barat. 2017. Provinsi Sumatera Barat Dalam Angka. CV. Graphic Dwipa, Sumatera Barat.

Fadhli. 2014. Perbedaan peternakan ayam broiler yang bermitra dengan PT.PKP (Prima Karya Persada), dan UD. Harco di Kecamatan Bajeng Kabupaten Gowa. Skripsi. Universitas Hasanuddin., Makassar.

Hardjosworo, P. S. dan Rukmiasih. 2000. Meningkatkan Produksi Daging Unggas. Penebar Swadaya, Depok.

Heriyatno, 2009. Analisis pendapatan dan faktor yangmempengaruhiproduksisususapiperah di tingkat peternak (Kasus anggota koperasi serba usaha "Karya Nugraha" Kecamatan Cigugur Kabupaten Kuningan Provinsi Jawa Barat). Skripsi Fakultas Pertanian. Institut Pertanian Bogor, Bogor.

Hoddi, A. H, M. B. Rombe, dan Fahrul. 2011. Analisis pendapatan peternakan sapi potong di Kecamatan Tanete Rilau, Kabupaten Barru (revenue analysis cattle ranch in sub tanete Rilau Barru). Jurnal Agribisnis, 10(3): 25-32.
Mahendra. 2014. Analisis pengaruh pendidikan, upah, jenis kelamin, usia dan pengalaman kerja terhadap produktifitas tenaga kerja (Studi kasus di industri kecil tempe, Kota Semarang) Fakultas Ekonomi dan Bisnis Universitas Diponegoro, Semarang.

Maulana, Y., Y. Mauludin, dan E. Ghunadi. 2014. Analisis usaha peternakan ayam ras pedaging (broiler) dengan pola kemitraan (studi kasus di peternakan Bu Lilis Rancamidin, Cibodas). Jurnal Kalibrasi, 12(1): 1-10.

Nina. 2013. Faktor-Faktor yang Mempengaruhi Usaha Ternak Sapi Potong di Kecamatan Tapanuli, Kabupaten Padang Sidempuan, Sumatera Utara.

Nizam,M.2013. Analisa pendapatan peternakayam broiler pada pola kemitraan yang berbeda di Kecamtan Tellusiattinge Kabupaten Bone. Skripsi. Universitas Hasanduddin, Makassar.

Ratnasari, R., W. Siringat dan A. Setiadi. 2015. Analisis pendapatan peternak ayam broiler pada sistem kemitraan di Kecamatan Gunung Pati Kota Semarang. Animal Agriculture Journal, 4(1): 47-53.

Simanjuntak. 2002. Masalah Upah dan Jaminan Sosial dalam Undang-Undang yang baru tentang Serikat Pekerja/Serikat Buruh. Kantor Pemburuhan Internasional, Jakarta.

Siregar, A.P. 2005. Teknik Beternak Ayam Ras di Indonesia. Margie group, Jakarta.

Soekartawi. 2006. Analisis Usaha Tani. Universitas Indonesia Press, Jakarta.

Windarsari, L. D. 2012. Kajian usaha peternakan ayam ras pedaging di kabupaten Karang anyar:membandingkanantara polakemitraan dan pola mandiri. Jurnal Ilmu Pertanian dan Perikanan, 1(1) : 65-72.

Yunus, M., M. A. Saade dan K. Ekasari. 2007. Analisis usaha peternakan ayam broiler (studi kasus pada usaha peternakan ayam broiler di kelurahan Boronghae, kecamatan Bontomarannu, kabupaten Gowa). Jurnal Agripola, 3(1): 54-59.

Yunus, R. 2009. Analisis Efisiensi Produksi Usaha Peternakan Ayam Ras Pedaging Pola Kemitraan dan Mandiri di Kota Palu Provinsi Sulawesi Tengah. Thesis Program Pascasarjana. Universitas Diponegoro, Semarang. 